\title{
Analisis Kinerja Keuangan pada PT.Ace Hardware Indonesia Tbk
}

\author{
Nur Qomariah
}

Sekolah Tinggi Ilmu Ekonomi Bima

qomariahnur125@gmail.com

\section{Alwi}

Sekolah Tinggi Ilmu Ekonomi Bima

alwi_muhammad1317@yahoo.co.id

\begin{abstract}
Abstrak This study aims to analyze the financial performance of Pt Ace Hardware Indonesia Tbk using the ratio of Return on Assets, Return on Equity, Net Profit Margin, and Gross Profit Margin. This type of research is descriptive using quantitative data from secondary data sources. The research instrument used is the income statement and financial position report for 10 years from 2010-2019. The population used is the financial report notes of Pt Ace Hardware Indonesia tbk 13 years from 2007-2019 and the research sample for 10 years from 20102019 with the sampling used is purposive sampling. The data analysis technique used descriptive per component analysis. In this study, data analysis of one-party t-test (One Sample t-test) was also used. The results showed that: T_count for Return on Asset (ROA), Return on Equity (ROE), Net Profit Margin (NPM) is smaller than t table so it states that Return on Asset (ROA), Return on Equity (ROE), Net Profit Margin (NPM) ) on bad Pt.Ace Hardware Indonesia Tbk. Whereas for $T$, the Gross Profit Margin is greater than the t table, so it states that the Gross Profit Margin at Pt Ace Hardware Indonesia Tbk is healthy.
\end{abstract}

Kata Kunci Kinerja Keuangan, Return on Asset, Return on Equity, Net Profit Margin, Gross Profit Margin

\section{PENDAHULUAN}

Bagi setiap perusahaan baik yang besar maupun kecil,yang berorentasi profit maupun yang non profit akan mempunyai perhatian yang besar terhadap keuangan dari perusahaan tersebut. Keberhasilan maupun kegagalan dalam usahanya hampir sebagian dipengaruhi ataupun ditentukan oleh keputusan keuangan perusahaan tersebut. Dengan kata lain masalah yang biasa timbul dalam setiap organisasi berimplikasi terhadap bidang keuangan.

Salah satu cara yang dapat digunakan untuk melihat kinerja keuangan adalah laporan keuangan. Laporan keuangan merupakan objek dari analisis keuangan. Dalam laporan keuangan ada empat jenis laporan, yaitu (1) neraca, (2) laporan laba-rugi, (3) 
laporan arus kas dan (4) laporan posisi keuangan. Tetapi, tidak cukup hanya melihat laporan keuangan saja. Laporan keuangan dapat memberikan sebuah informasi yang bermanfaat jika sudah dilakukan sebuah analisis laporan keuangan. Analisis laporan keuangan digunakan sebagai acuan atau sebagai dasar pengambilan sebuah keputusan. Yang sering digunakan pada umumnya dalam melakukan analisis adalah perhitungan rasio-rasio keuangan, antara lain yang umum digunakan adalah rasio Profitabilitas.

Analisis rasio profitabilitas merupakan rasio yang digunakan untuk mengukur kemampuan perusahaan dalam menghasilkan laba dari aktivitas normal bisnisnya. Disamping bertujuan untuk mengetahui kemampuan perusahaan dalam menghasilkan laba selama periode tertentu, rasio ini juga bertujuan untuk mengukur tingkat efektivitas manajemen dalam menjalankan operasional perusahaan.

Bagi setiap perusahaan baik yang besar maupun kecil,yang berorentasi profit maupun yang non profit akan mempunyai perhatian yang besar terhadap keuangan dari perusahaan tersebut. Keberhasilan maupun kegagalan dalam usahanya hampir sebagian dipengaruhi ataupun ditentukan oleh keputusan keuangan perusahaan tersebut. Dengan kata lain masalah yang biasa timbul dalam setiap organisasi berimplikasi terhadap bidang keuangan.

Salah satu cara yang dapat digunakan untuk melihat kinerja keuangan adalah laporan keuangan. Laporan keuangan merupakan objek dari analisis keuangan. Dalam laporan keuangan ada empat jenis laporan, yaitu (1) neraca, (2) laporan laba-rugi, (3) laporan arus kas dan (4) laporan posisi keuangan. Tetapi, tidak cukup hanya melihat laporan keuangan saja. Laporan keuangan dapat memberikan sebuah informasi yang bermanfaat jika sudah dilakukan sebuah analisis laporan keuangan. Analisis laporan keuangan digunakan sebagai acuan atau sebagai dasar pengambilan sebuah keputusan. Yang sering digunakan pada umumnya dalam melakukan analisis adalah perhitungan rasio-rasio keuangan, antara lain yang umum digunakan adalah rasio Profitabilitas.

Analisis rasio profitabilitas merupakan rasio yang digunakan untuk mengukur kemampuan perusahaan dalam menghasilkan laba dari aktivitas normal bisnisnya. Disamping bertujuan untuk mengetahui kemampuan perusahaan dalam menghasilkan laba selama periode tertentu, rasio ini juga bertujuan untuk mengukur tingkat efektivitas manajemen dalam menjalankan operasional perusahaan.

Pt.Ace Hardware Indonesia Tbk adalah sebuah perusahaan ritel yang bergerak dalam bidang perlengkapan rumah dan produk gaya hidup. Pada akhir tahun 2016, perusahaan ini mengelola jaringan dari 129 toko ritel di 34 kota besar di Indonesia. Dengan total area lantai toko yang lebih luas dari 336.000 meter persegi. Pt.Ace Hardware Indonesia Tbk adalah pemegang waralaba (franchise) merek ACE Hardware (ditunjuk oleh ACE Hardware Corporation yang berbasis di AS). Pt.Ace Hardware Indonesia Tbk didirikan pada tanggal 6 Februari 1995. Dan terdaftar di BEI pada tanggal 6 November 2007 dengan jumlah saham yang tercatat 1.715.000.000, (www.indonesiainvestment.com)

Grafik 1 merupakan data grafik Kinerja Keuangan Pt.Ace Hardware Indonesia Tbk bila ditinjau dari komponen laba kotor, total asset, total ekuitas, penjualan dan laba kotornya : 
Grafik 1. Laba Kotor, Total Asset, Total Ekuitas, Penjualan dan Laba Kotor Keuangan Pt.Ace Hardware Indonesia Tbk

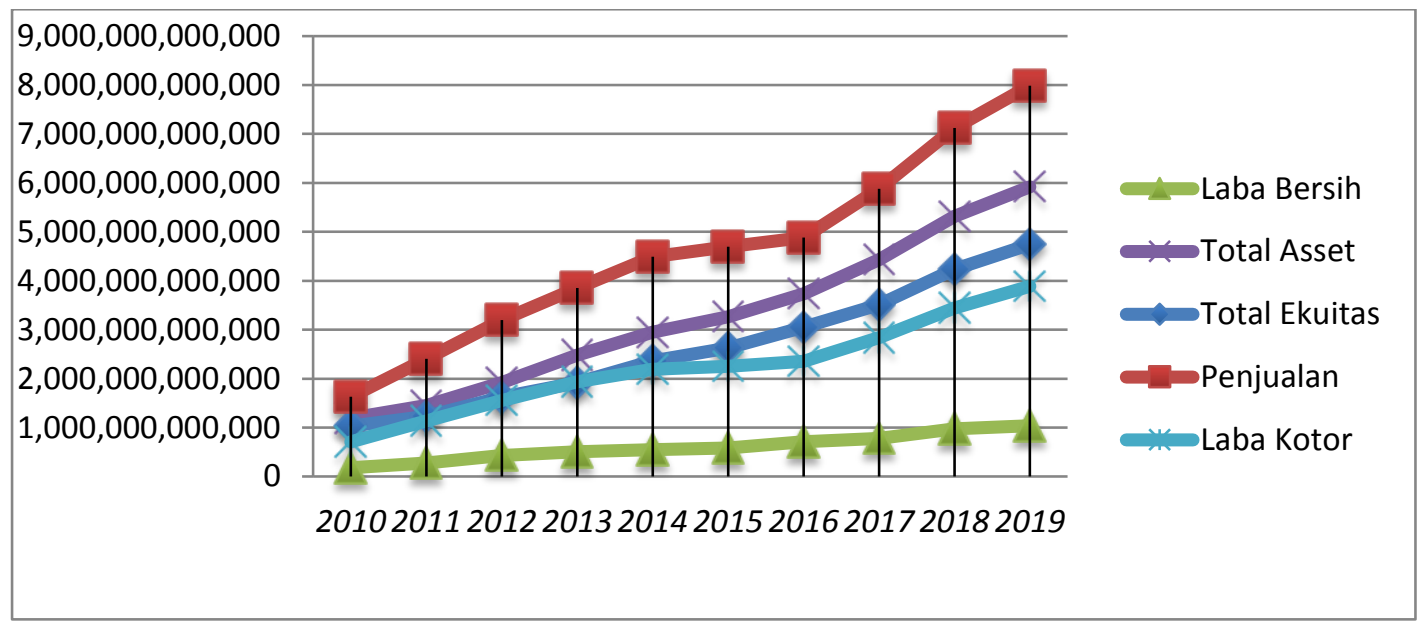

Sumber: Data Sekunder Diolah 2021

Dari grafik 1 diatas terlihat bahwa laba bersih dan total asset Pt.Ace Hardware Indonesia Tbk menunjukkan kinerja yang baik, ini terlihat dengan stabilnya pergerakan grafik dari tahun 2010-2019. Laba bersih Pt.Ace Hardware Indonesia Tbk pada tahun 2010 total sebanyak Rp177.851.336.490 terus naik hingga mencapai angka Rp 1.036.610.556.510 ditahun 2019, begitupun halnya dengan total asset Pt.Ace Hardware Indonesia Tbk yang pada tahun 2010 total sebanyak Rp 1.191.333.479.259 terus meningkat sampai sebanyak Rp 5.920.169.803.449 di tahun 2019.

Sama halnya dengan laba bersih dan total asset, total ekuitas dan penjualan Pt.Ace Hardware Indonesia Tbk juga mengalami kenaikan yang stabil dari tahun ke tahunnya. Total ekuitas Pt.Ace Hardware Indonesia Tbk pada tahun 2010 sebanyak Rp 1.030.137.766.407 naik sampai total sebanyak Rp 4.742.494.275.864 di tahun 2019. Sedangkan penjualan Pt.Ace Hardware Indonesia Tbk pada tahun 2010 yaitu sejumlah Rp 1.628.438.357.211 terus naik sampai tahun 2019 dengan jumlah penjualannya adalah sebanyak Rp 7.986.528.789.676.

Meskipun laba bersih, total asset, total ekuitas dan penjualan Pt.Ace Hardware Indonesia Tbk cukup stabil kenaikannya dari tahun ke tahun, namun kenaikan tersebut tidak signifikan, hanya bergerak sedikit saja dari posisi awalnya padahal Pt.Ace Hardware Indonesia Tbk adalah salah satu perusahaan besar yang mempunyai anak perusahaan hampir diseluruh Indonesia, fenomena ini diakibatkan karena pembukaan beberapa gerai baru, sebagai konsekuensi program ekspansi yang agresif.

Dalam penelitian Rahmah \& Komariah (2016), dengan judul penelitian "Analisis Laporan Keuangan dalam Menilai Kinerja Keuangan Industri Semen yang terdaftar di BEI (Studi Kasus PT. Indocement Tunggal Prakarsa Tbk)”. Hasil penelitian rasio-rasio secara keseluruhan, keadaan perusahaan sudah baik dalam menghasilkan laba maupun dalam pelunasan hutanghutangnya, tetapi dalam mengelola modal dan asetnya, perusahaan belum secara efisien. 
Dalam penelitian Siboro, dkk (2017), dengan judul penelitan “Analisis Kinerja Keuangan pada Perusahaan Konstruksi yang terdaftar di Bursa Efek Indonesia (BEI) pada periode 2011-2015". Hasil penelitian menunjukkan bahwa kinerja perusahaan konstruksi secara keseluruhan masih belum maksimal. Hal tersebut terlihat pada rasio profitabilitasnya khususnya pada rasio GPM, NPM, ROA, dan ROEnya. kinerja keuangan rata-rata pada perusahaan konstruksi mengalami berfluktuasi.

Penelititian selanjutnya yang dilakukan oleh Sipahelut, dkk (2017), dengan judul penelitian "Analisis Kinerja Keuangan Perusahaan (Studi Kasus Pada Perusahaan Sub Sektor Otomotif Dan Komponen Yang Terdaftar di BEI periode 2014-2016)". Hasil penelitian menunjukan bahwa kinerja keuangan perusahaan sub sektor otomotif dan komponen yang terdaftar di BEI periode 2014-2016 berdasrkan rasio profitabilitas sduah baik.

Berdasarkan penelitian-penelitian terdahulu, peneliti tertarik untu melakukan penelitian dengan judul "Analisis Kinerja Keuangan pada PT.Ace Hardware Indonesia Tbk". Tujuan penelitian ini adalah untuk: 1) menganalisis Return On Asset sebagai rasio profitabilitas dalam menilai kinerja keuangan pada PT.Ace Hardware Indonesia Tbk, 2) untuk menganalisis Return On Equity sebagai rasio profitabilitas dalam menilai kinerja keuangan pada PT.Ace Hardware Indonesia Tbk, 3) untuk menganalisis Net Profit Margin sebagai rasio profitabilitas dalam menilai kinerja keuangan pada PT.Ace Hardware Indonesia Tbk, 4) untuk menganalisis Gross Profit Margin sebagai rasio profitabilitas dalam menilai kinerja keuangan pada PT.Ace Hardware Indonesia Tbk.

\section{LANDASAN TEORI}

\section{A. Kinerja Keuangan}

Menurut Fahmi (2014:2), Kinerja keuangan adalah gambaran tentang keberhasilan perusahaan berupa hasil yang telah dicapai berkat berbagai aktivitas yang telah dilakukan. Kinerja keuangan merupakan suatu analisis untuk menilai sejauh mana suatu perusahaan telah melaksanakan aktivitas sesuai aturan-aturan pelaksanaan keuangan.

Kinerja keuangan dapat dinilai dengan beberapa alat analisis, salah satunya yaitu analisis perbandingan laporan keuangan dengan cara membandingkan laporan keuangan dua periode atau lebih dengan menunjukkan perubahan, baik dalam jumlah " absolut" maupun dalam presentase " relatif".

\section{B. Rasio Profitabilitas}

Menurut Kasmir (2016:104) Rasio profitabilitas adalah rasio untuk menilai kemampuan perusahaan dalam mencari keuntungan. Rasio ini menunjukkan gambaran tentang tingkat efektivitas pengelolaan perusahaan dalam menghasilkan laba selama periode tertentu.

\section{METODOLOGI PENELITIAN}

Pendekatan yang dilakukan dalam penelitian ini adalah menggunakan pendekatan deskriptif dengan menggunakan perhitungan terhadap data-data kuantitatif yang berupa laporan keuangan dengan tujuan untuk mengetahui kinerja keuangan Pt.Ace Hardware Indonesia tbk.Penelitian ini dilakukan melalui pengambilan data yaitu data sekunder dimana telah disediakan oleh perusahaan berupa annual report. Instrument penelitian 
yang digunakan yaitu laporan laba-rugi dan laporan posisi keuangan selama 10 tahun dari tahun 2010-2019. Populasi yang digunakan yaitu catatan laporan keuangan Pt.Ace Hardware Indonesia tbk 13 tahun dari tahun 2007-2019 dan sampel penelitian selama 10 tahun dari tahun 2010-2019 dengan sampling yang digunakan yaitu purposive sampling. Pengukuran rasio profitabilitas terdiri dari:

1) Return On Assets (ROA)

Yaitu membandingkan laba bersih setelah pajak dengan total aktiva. Rasio ini menunjukkan kemampuan perusahaan untuk menghasilkan laba berdasarkan total aktiva yang dimiliki perusahaan (Kasmir,2014).

Menurut Kasmir (2014), rumus yang digunakan sebagai alat ukur rasio Return On Assets adalah :

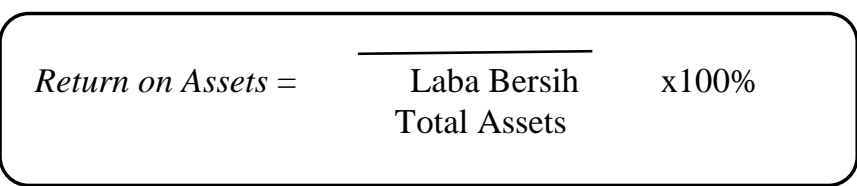

2) Return On Equity (ROE)

Menurut Kasmir (2014 : 206), ROE digunakan sebagai alat ukur laba bersih dengan total ekuitas. Rasio Return On Equity ini menunjukan efisiensi penggunaan ekuitas perusahaan. Apabila rasio ini semakin tinggi, maka semakin baik. Itu artinya posisi perusahaan akan semakin kuat, begitupula sebaliknya.

Menurut (Kasmir 2014), rumus yang digunakan sebagai alat ukur rasio Return On Equity adalah:

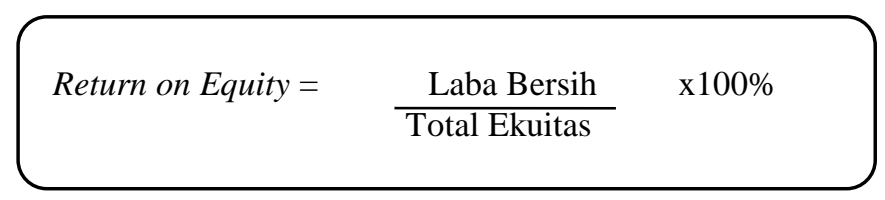

\section{3) Gross Profit Margin (GPM)}

Gross Profit Margin merupakan presentase laba kotor dibandingkan dengan sales. Semakin besar GPM semakin baik keadaan operasi perusahaan, karena hal ini menunjukkan bahwa harga pokok penjualan cenderung lebih rendah dibandingkan dengan harga sales, begitu pula sebaliknya semakin rendah GPM akan semakin kurang baik operasi pada perusahaan (Syamsuddin, 2011:61).

Rumus yang digunakan untuk mengukur rasio Gross Profit Margin dalam Adisetiawan (2012) yaitu :

$$
\text { Gross Profit Margin }=\frac{\text { Laba Kotor }}{\text { Penjualan }} \times 100 \%
$$


4) Net Profit Margin (NPM)

Adalah rasio yang menunjukkan berapa besar persentase laba bersih yang diperoleh dari setiap penjualan (Kasmir,2008).

Menurut Kasmir (2016), rumus yang digunakan untuk mengukur rasio Net Profit Margin adalah :

$$
\text { Net Profit Margin }=\quad \frac{\text { Laba Bersih }}{\text { Penjualan }} \times 100 \%
$$

Dalam penelitian ini, digunakan juga analisis data uji t satu pihak ( $t$-test One Sample). SPSS versi 21 (Ghozali, 2016). Teknik analisis ini digunakan karena variabel dalam penelitin ini adalah hanya 1 variabel.

Table 1. Standar Rasio Industri Profitabilitas

\begin{tabular}{|l|l|l|}
\hline No & Jenis Rasio & Standar Industri \\
\hline 1 & Return on Assets & $30 \%$ \\
\hline 2 & Return on Equity & $40 \%$ \\
\hline 3 & Net Profit Margin & $20 \%$ \\
\hline 4 & Gross Profit Margin & $30 \%$ \\
\hline
\end{tabular}

Sumber : Kasmir (2014:208)

\section{HASIL PENELITIAN}

Berdasarkan data yang diperoleh dari Pt.Ace Hardware Indonesia Tbk periode 2010-2019, dapat dilihat fenomena Return On Asset, Return On Equity, Net Profit Margin, dan Gross Profit Margin yang terjadi dalam perusahaan tersebut adalah sebagai berikut :

\section{a. Return On Assets (ROA)}

1. Analisa Deskriptif Return On Assets (ROA)

Tabel 2. Hasil Return On Assets (ROA) pada PT.Ace Hardware Indonesia Tbk periode 2010-2019

\begin{tabular}{cccc}
\hline Tahun & Laba bersih & Total asset & ROA \\
\hline 2010 & 177.851 .336 .490 & 1.191 .333 .479 .259 & $14,9 \%$ \\
2011 & 279.504 .732 .018 & 1.451 .755 .376 .484 & $14,0 \%$ \\
2012 & 428.849 .175 .516 & 1.916 .914 .650 .213 & $22,4 \%$ \\
2013 & 503.004 .238 .918 & 2.478 .918 .548 .338 & $20,3 \%$ \\
2014 & 548.892 .765 .278 & 2.947 .348 .661 .224 & $18,6 \%$ \\
2015 & 584.873 .463 .989 & 3.267 .549 .674 .003 & $17,9 \%$ \\
2016 & 706.150 .082 .276 & 3.731 .101 .667 .891 & $18,9 \%$ \\
2017 & 780.686 .814 .661 & 4.428 .840 .550 .479 & $17,6 \%$ \\
2018 & 976.273 .356 .597 & 5.321 .180 .855 .541 & $18,3 \%$ \\
2019 & 1.036 .610 .556 .510 & 5.920 .169 .803 .449 & $17,5 \%$ \\
\hline
\end{tabular}

Sumber : Data sekunder laporan keuangan PT.Ace Hardware Indonesia Tbk 
Dari tabel diatas dapat dilihat bahwa pada Rasio Return on Asset (ROA) adanya penurunan dari tahun ketahun, artinya perusahaan mengalami penurunan terhadap laba bersih yang diperoleh perusahaan yang diukur dari nilai aktiva. Dari standar rasio perusahaan, Pt.Ace Hardware Indonesia tbk masih berada dibawah rata-rata.

2. Uji-T Return On Assets (ROA)

Tabel 3. Hasil t hitung One Sample Test Return On Assets (ROA)

\begin{tabular}{|c|c|c|c|c|c|c|}
\hline \multicolumn{7}{|c|}{ One-Sample Test } \\
\hline & \multicolumn{6}{|c|}{ Test Value $=30$} \\
\hline & \multirow[t]{4}{*}{$\mathrm{T}$} & \multirow[t]{4}{*}{ Df } & \multirow{4}{*}{$\begin{array}{l}\text { Sig. (2- } \\
\text { tailed) }\end{array}$} & \multirow{4}{*}{$\begin{array}{c}\text { Mean } \\
\text { Differenc } \\
\mathrm{e}\end{array}$} & \multirow{3}{*}{\multicolumn{2}{|c|}{$\begin{array}{l}95 \% \text { Confidence } \\
\text { Interval of the } \\
\text { Difference }\end{array}$}} \\
\hline & & & & & & \\
\hline & & & & & & \\
\hline & & & & & Lower & Upper \\
\hline Return on & & $\overline{\overline{9}}$ & 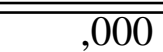 & $-11,9600$ & $\overline{-13,678}$ & $-10,242$ \\
\hline Asset & 15,74 & & & & & \\
\hline & 6 & & & & & \\
\hline
\end{tabular}

Sumber : data diolah dengan SPSS v20

Berdasarkan hasil olahan SPSS diatas maka nilai t hitung untuk Return on Asset adalah sebesar $-15,746$ kemudian nilai t hitung tersebut akan dibandingkan dengan nilai $\mathrm{t}$ tabel dengan derajat kebebasan $(\mathrm{dk})=\mathrm{n}-\mathrm{k}=10-1=9$ dan taraf kesalahan $5 \%$ untuk uji satu pihak (one tail test) pihak kiri didapat nilai t tabel (pada daftar distribusi t) adalah sebesar 2.262. jika dibandingkan antara nilai t tabel dangan t hitung, maka t hitung lebih kecil dari pada $t$ tabel $(-15,746 \leq 2.262)$ Sehingga hipotesis pertama jatuh pada daerah penerimaan Ho yang berarti diterima Ho dan Ha ditolak. Sehingga hal ini menjawab dan membuktikan hipotesis pertama yang menyatakan bahwa "Return on Assets pada Pt.Ace Hardware Indonesia Tbk kurang dari atau sama dengan $30 \%$ dari yang diharapkan (buruk)".

\section{b. Return On Equity (ROE)}

1. Analisa Deskriptif Return On Equity (ROE)

Tabel 4. Hasil Return On Equity (ROE) pada PT.Ace Hardware Indonesia Tbk periode 2010-2019

\begin{tabular}{lccc}
\hline Tahun & Laba bersih & Total Ekuitas & ROE \\
\hline 2010 & 177.851 .336 .490 & 1.030 .137 .766 .407 & $17,3 \%$ \\
2011 & 279.504 .732 .018 & 1.231 .873 .738 .659 & $22,7 \%$ \\
2012 & 428.849 .175 .516 & 1.618 .001 .039 .174 & $26,5 \%$ \\
2013 & 503.004 .238 .918 & 1.915 .498 .438 .092 & $26,3 \%$ \\
2014 & 548.892 .765 .278 & 2.362 .148 .245 .370 & $23,2 \%$ \\
2015 & 584.873 .463 .989 & 2.628 .825 .516 .460 & $22.2 \%$ \\
2016 & 706.150 .082 .276 & 3.048 .727 .694 .796 & $23,2 \%$ \\
2017 & 780.686 .814 .661 & 3.510 .421 .847 .790 & $22,2 \%$ \\
2018 & 976.273 .356 .597 & 4.235 .471 .045 .929 & $23,0 \%$ \\
2019 & 1.036 .610 .556 .510 & 4.742 .494 .275 .864 & $21,9 \%$ \\
\hline
\end{tabular}

Sumber : Data sekunder laporan keuangan PT.Ace Hardware Indonesia Tbk

Dilihat dari tahun ketahun return on equity ratio mengalami naik turun. Dan pada tahun 2014 perusahaan mengalami penurunan karena modal pemilik lebih besar dari pada 
laba bersih yang diperoleh. Sehingga perusahaan mendapatkan sedikit keuntungannya. Dari rata-rata rasio perusahaan Pt.Ace Hardware Indonesia tbk masih berada dibawah standar. Ini menunjukan bahwa perusahaan masih memperoleh laba yang kecil.

\section{Uji-T Return On Equity (ROE)}

Tabel 5. Hasil t hitung One Sample Test Return On Equity (ROE)

\begin{tabular}{|c|c|c|c|c|c|c|}
\hline \multicolumn{7}{|c|}{ One-Sample Test } \\
\hline & \multicolumn{6}{|c|}{ Test Value $=40$} \\
\hline & \multirow[t]{2}{*}{$\mathrm{T}$} & \multirow[t]{2}{*}{ Df } & \multirow[t]{2}{*}{$\begin{array}{l}\text { Sig. (2- } \\
\text { tailed) }\end{array}$} & \multirow[t]{2}{*}{$\begin{array}{c}\text { Mean } \\
\text { Differenc } \\
\mathrm{e}\end{array}$} & \multicolumn{2}{|c|}{$\begin{array}{l}95 \% \text { Contidence } \\
\text { Interval of the } \\
\text { Difference }\end{array}$} \\
\hline & & & & & Lower & Upper \\
\hline Return on & - & 9 &, 000 & $-17,1500$ & $-18,967$ & $-15,333$ \\
\hline Equity & $\begin{array}{r}21,35 \\
1\end{array}$ & & & & & \\
\hline
\end{tabular}

Sumber : data diolah dengan SPSS v20

Berdasarkan hasil olahan SPSS pada tabel 5 maka nilai t hitung untuk Return on Equity adalah sebesar 21,351 kemudian nilai t hitung tersebut akan dibandingkan dengan nilai $\mathrm{t}$ tabel dengan derajat kebebasan $(\mathrm{dk})=\mathrm{n}-\mathrm{k}=10-1=9$ dan taraf kesalahan $5 \%$ untuk uji satu pihak (one tail test) pihak kiri didapat nilai t tabel (pada daftar distribusi t) adalah sebesar 2.262. jika dibandingkan antara nilai t tabel dangan $t$ hitung, maka t hitung lebih kecil dari pada t tabel $(-21,351 \leq 2.262)$ Sehingga hipotesis kedua jatuh pada daerah penerimaan Ho yang berarti diterima Ho dan Ha ditolak. Sehingga hal ini menjawab dan membuktikan hipotesis kedua yang menyatakan bahwa "Return on Equity pada Pt.Ace Hardware Indonesia Tbk kurang dari atau sama dengan $40 \%$ dari yang diharapkan (buruk)".

\section{c. Net Profit Margin (NPM)}

1. Analisa Deskriptif Net Profit Margin (NPM)

Tabel 6. Hasil Net Profit Margin (NPM) pada PT.Ace Hardware Indonesia Tbk Periode 2010-2019

\begin{tabular}{cccc}
\hline Tahun & Laba bersih & Penjualan & NPM \\
\hline 2010 & 177.851 .336 .490 & 1.628 .438 .357 .211 & $10,5 \%$ \\
2011 & 279.504 .732 .018 & 2.406 .033 .973 .944 & $11,2 \%$ \\
2012 & 428.849 .175 .516 & 3.193282 .818 .586 & $12,9 \%$ \\
2013 & 503.004 .238 .918 & 3.850 .300 .588 .204 & $12,5 \%$ \\
2014 & 548.892 .765 .278 & 4.492 .197 .911 .790 & $11,8 \%$ \\
2015 & 584.873 .463 .989 & 4.694 .947 .302 .382 & $12,0 \%$ \\
2016 & 706.150 .082 .276 & 4.884 .064 .456 .253 & $13,9 \%$ \\
2017 & 780.686 .814 .661 & 5.877 .966 .660 .390 & $12,8 \%$ \\
2018 & 976.273 .356 .597 & 7.124 .230 .646 .381 & $13,0 \%$ \\
2019 & 1.036 .610 .556 .510 & 7.986 .528 .789 .676 & $12,1 \%$ \\
\hline
\end{tabular}

Sumber : Data sekunder laporan keuangan PT.Ace Hardware Indonesia Tbk 
Berdasarkan hasil olahan SPSS pada tabel 6 diketahui bahwa kondisi Net Profit Margin (NPM) pada tahun 2010 sampai dengan 2013 mengalami peningkatan penjualan. Pada tahun 2014 net profit marjin mengalami penurunan. Dan pada tahun 2015 Net Profit Margin kembali mengalami peningkatan.

Hal ini menunjukkan bahwa penjualan mengalami kenaikan dengan hasil laba bersih mengalami penurunan. Maka dapat ditarik kesimpulan bahwa Net Profit Margin (NPM) mengalami penurunan dikarenakan tingginya total penjualan yang tidak diikuti dengan laba bersih yang didapatkan perusahaan. Rendahnya Net Profit Margin, karena tingginya beban-beban yang dimiliki perusahaan seperti beban administrasi sehingga penjualan yang tinggi tidak mampu memberikan laba yang tinggi bagi perusahaan.

2. Uji-T Net Profit Margin (NPM)

Tabel 7. Hasil t hitung One Sample Test Net Profit Margin (NPM)

\begin{tabular}{|c|c|c|c|c|c|c|}
\hline \multicolumn{7}{|c|}{ One-Sample Test } \\
\hline & \multicolumn{6}{|c|}{ Test Value $=20$} \\
\hline & \multirow[t]{2}{*}{$\mathrm{T}$} & \multirow[t]{2}{*}{ Df } & \multirow[t]{2}{*}{$\begin{array}{l}\text { Sig. (2- } \\
\text { tailed) }\end{array}$} & \multirow[t]{2}{*}{$\begin{array}{l}\text { Mean } \\
\text { Differen } \\
\text { ce }\end{array}$} & \multicolumn{2}{|c|}{$\begin{array}{l}95 \% \text { Confidence } \\
\text { Interval of the } \\
\text { Difference }\end{array}$} \\
\hline & & & & & Lower & Upper \\
\hline Net Profit & - & 9 & ,000 & $-7,7300$ & $-8,426$ & $-7,034$ \\
\hline Margin & $\begin{array}{r}25,12 \\
2 \\
\end{array}$ & & & & & \\
\hline
\end{tabular}

Sumber : data diolah dengan SPSS v20

Berdasarkan hasil olahan SPSS pada tabel 7 maka nilai t hitung untuk Net Profit Margin adalah sebesar 25,122 kemudian nilai t hitung tersebut akan dibandingkan dengan nilai t tabel dengan derajat kebebasan $(\mathrm{dk})=\mathrm{n}-\mathrm{k}=10-1=9$ dan taraf kesalahan $5 \%$ untuk uji satu pihak (one tail test) pihak kiri didapat nilai t tabel (pada daftar distribusi t) adalah sebesar 2.262. jika dibandingkan antara nilai t tabel dangan thitung, maka $t$ hitung lebih kecil dari pada t tabel $(-25,122 \leq 2.262)$ Sehingga hipotesis ketiga jatuh pada daerah penerimaan Ho yang berarti Ho diterima dan Ha ditolak. Sehingga hal ini menjawab dan membuktikan hipotesis ketiga yang menyatakan bahwa "Net Profit Margin pada Pt.Ace Hardware Indonesia Tbk kurang dari atau sama dengan 20\% dari yang diharapkan (buruk)".

\section{d. Gross Profit Margin (GPM)}

1. Analisa Deskriptif Gross Profit Margin (GPM)

Tabel 8

Hasil Gross Profit Margin (GPM) pada PT.Ace Hardware Indonesia Tbk periode 2010-2019

\begin{tabular}{cccc}
\hline Tahun & Laba kotor & Penjualan & GPM \\
\hline 2010 & 708.602 .815 .190 & 1.628 .438 .357 .211 & $45,5 \%$ \\
2011 & 1.136 .174 .634 .214 & 2.406 .033 .973 .944 & $45,8 \%$ \\
2012 & 1.551 .576 .243 .757 & 3.193282 .818 .586 & $46,4 \%$ \\
\hline
\end{tabular}




\begin{tabular}{llll}
\hline 2013 & 1.933 .548 .645 .987 & 3.850 .300 .588 .204 & $46,3 \%$ \\
2014 & 2.193 .584 .429 .818 & 4492.197 .911 .790 & $46,2 \%$ \\
2015 & 2.253 .716 .894 .547 & 4.694 .947 .302 .382 & $47,0 \%$ \\
2016 & 2.351 .756 .504 .844 & 4.884 .064 .456 .253 & $48,1 \%$ \\
2017 & 2.834 .716 .138 .814 & 5.877 .966 .660 .390 & $46,8 \%$ \\
2018 & 3.443 .158 .197 .607 & 7.124 .230 .646 .381 & $45,5 \%$ \\
2019 & 3.887 .090 .318 .844 & 7.986 .528 .789 .676 & $41,9 \%$ \\
\hline
\end{tabular}

Sumber : Data sekunder laporan keuangan PT.Ace Hardware Indonesia Tbk

Gross Profit Margin dari tahun ketahun mengalami peningkatan disebabkan karena meningkatnya total Penjualan yang seimbang dengan laba yang dimiliki perusahaan. Artinya perusahaan Pt.Ace Hardware Indonesia tbk dengan persentase standar rasio diatas $30 \%$ sudah dianggap sangat baik. Dari standar rasio perusahaan Pt.Ace Hardware Indonesia tbk berada diatas rata-rata.

2. Uji-T Gross Profit Margin (GPM)

Tabel 9. Hasil t hitung One Sample Test Gross Profit Margin (GPM)

\begin{tabular}{|c|c|c|c|c|c|c|}
\hline \multicolumn{7}{|c|}{ One-Sample Test } \\
\hline & \multicolumn{6}{|c|}{ Test Value $=30$} \\
\hline & \multirow[t]{2}{*}{$\mathrm{t}$} & \multirow[t]{2}{*}{ Df } & \multirow[t]{2}{*}{$\begin{array}{l}\text { Sig. (2- } \\
\text { tailed) }\end{array}$} & \multirow[t]{2}{*}{$\begin{array}{c}\text { Mean } \\
\text { Differe } \\
\text { nce }\end{array}$} & \multicolumn{2}{|c|}{$\begin{array}{l}95 \% \text { Confidence } \\
\text { Interval of the } \\
\text { Difference }\end{array}$} \\
\hline & & & & & Lower & Upper \\
\hline Gross & 3,77 & 9 & ,004 & 12,9700 & 5,191 & 20,749 \\
\hline $\begin{array}{l}\text { Profit } \\
\text { Margin }\end{array}$ & 2 & & & & & \\
\hline
\end{tabular}

Sumber : data diolah dengan SPSS v20

Berdasarkan hasil olahan SPSS dpada tabel 9 maka nilai t hitung untuk Gross Profit Margin adalah sebesar 3,772 kemudian nilai t hitung tersebut akan dibandingkan dengan nilai $\mathrm{t}$ tabel dengan derajat kebebasan $(\mathrm{dk})=\mathrm{n}-\mathrm{k}=10-1=9$ dan taraf kesalahan $5 \%$ untuk uji satu pihak (one tail test) pihak kiri didapat nilai t tabel (pada daftar distribusi $\mathrm{t}$ ) adalah sebesar 2.262. jika dibandingkan antara nilai t tabel dangan $t$ hitung, maka t hitung lebih besar dari pada t tabel $(3,772 \geq 2.262)$ Sehingga hipotesis keempat jatuh pada daerah penerimaan Ha yang berarti Ha diterima dan Ho ditolak. Sehingga hal ini menjawab dan membuktikan hipotesis keempat yang menyatakan bahwa "Gross Profit Margin pada Pt.Ace Hardware Indonesia Tbk lebih dari 30\% dari yang diharapkan (sehat)".

\section{KESIMPULAN}

Kesimpulan yang dapat diambil dari pembahasan analisa data yang telah dilakukan diatas adalah: kecuali Gross Profit Margin, tingkat persentase rasio Return on Asset ( ROA), Return on Equity (ROE) dan Net Profit Margin (NPM) pada Pt.Ace Hardware Indonesia Tbk dari tahun 2010-2019 tidak memenuhi standar industri yang telah ditetapkan. T_hitung untuk Return on Asset ( ROA), Return on Equity (ROE), Net 
Profit Margin (NPM) lebih kecil dari pada t tabel sehingga menyatakan bahwa Return on Asset ( ROA), Return on Equity (ROE), Net Profit Margin (NPM) pada Pt.Ace Hardware Indonesia Tbk buruk. Sedangkan untuk T hitung untuk Gross Profit Margin lebih besar dari pada t tabel sehingga menyatakan bahwa Gross Profit Margin pada Pt.Ace Hardware Indonesia Tbk sehat. Kecuali hipotesis keempat, hipotesis pertama, kedua dan ketiga berada pada daerah penerimaan $\mathrm{H}_{0}$ dan penolakan $\mathrm{H}_{\mathrm{a}}$

\section{DAFTAR PUSTAKA}

Fahmi, Irham. 2014. Analisis Kinerja Keuangan. Alfabeta. Bandung.

Ghozali. 2016. Aplikasi Analisis Multivariat dengan Program IBM SPSS. Semarang: Universitas Diponegoro.

Hery. 2018. Analisa Laporan Keuangan. Yogyakarta: Center For Academic Publising Servic

Kasmir. 2014. Analisis Laporan Keuangan. Jakarta: Rajawali Pers.

Kasmir. 2016. Analisis Laporan Keuangan, Edisi Pertama. PT Rajagrafindo Persada. Jakarta.

Laurent, Queen. 2014. Analisis Laporan Arus Kas Sebagai Alat Ukur Likuiditas Kinerja Keuangan Pada PT. Swakarya Indah Busana. Jurnal Ilmiah Sarjana Mahasiswa UMRAH. Universitas Maritim Raja Ali Haji Tanjungpinang. Diakses 4 Februari 2016. Hal. 2-19.

Natan, Fedrik. 2010. Analisis Laporan Keuangan untuk Menilai Kinerja Keuangan Pada PT. Astra International, Tbk Periode 2007-2009. Akurat Jurnal Ilmiah Akuntansi. No 3 Tahun ke-1 September-Desember 2010. Diakses 7 Agustus 2016. Hal. 1-17.

Rahmah, Nur, M, Komariah, Euis. 2016. Analisis Laporan Keuangan Dalam Menilai Kinerja Keuangan Industri Semen Yang Terdaftar Di BEI (Studi Kasus PT. Indocement Tunggal Prakarsa, Tbk). Jurnal Online Insan Akuntan, Vol.1, No.1, Juni 2016, 43 - 58. Akademi Akuntansi Bina Insani. Bekasi. Timur.

Siboro, Fransiskus, D. 2017. Analisis Kinerja Keuangan Pada Perusahaan Kontruksi Yang Terdaftar Di Bursa Efek Indonesia (BEI) Pada Periode 2011-2015. Jurnal EMBA, Vol. 5 No. 2 Juni 2017, Hal. 454 - 464.

Sipahelut, C.R, Murni, S, Rate, V.P. 2017. Analisis Kinerja Keuangan Perusahaan (Studi Kasus Pada Perusahaan Sub Sektor Otomotif Dan Komponen Yang Terdaftar Di BEI Periode 2014-2016). Jurnal EMBA. Vol.5 No.3 September 2017, Hal.44254434

Subani. 2015. Analisis Arus Kas Untuk Mengukur Kinerja Keuangan (Studi Pada KUD Sido Makmur Lumajang). Jurnal WIGA. Vol. 5 No. 1 Maret 2015. Diakses 4 Februari 2016. Hal. 59-67.

Sufriani, Rimawan, M. 2020. Analisis Return on Equity dan Debt to Equity Ratio. Owner: Riset dan Jurnal Akuntansi. Vol. 4 No. 2, Agustus 2020, Hal.308-316.

Sugiyono. (2014). Metode Penelitian Kuantitatif, Kualitatif dan R\&D . Bandung : Alfabeta. 